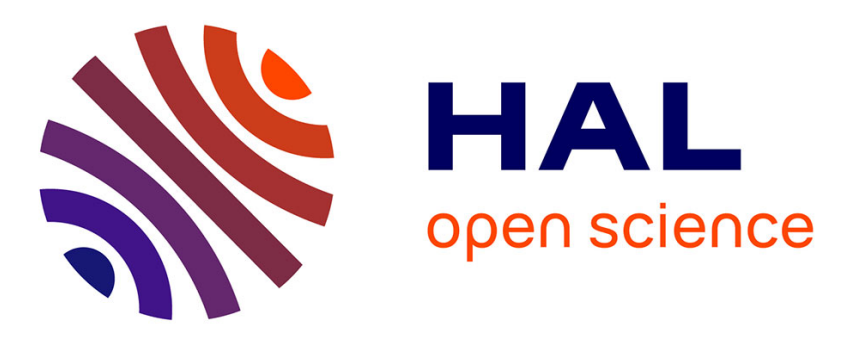

\title{
Mannose-targeted mesoporous silica nanoparticles for photodynamic therapy.
}

David Brevet, Magali Gary-Bobo, Laurence Raehm, Sébastien Richeter, Ouahiba Hocine, Kassem Amro, Bernard Loock, Pierre Couleaud, Céline Frochot, Alain Morère, et al.

\section{To cite this version:}

David Brevet, Magali Gary-Bobo, Laurence Raehm, Sébastien Richeter, Ouahiba Hocine, et al.. Mannose-targeted mesoporous silica nanoparticles for photodynamic therapy.. Chemical Communications, 2009, 12, pp.1475-7. 10.1039/b900427k . inserm-00375574

\section{HAL Id: inserm-00375574 https://www.hal.inserm.fr/inserm-00375574}

Submitted on 1 Apr 2010

HAL is a multi-disciplinary open access archive for the deposit and dissemination of scientific research documents, whether they are published or not. The documents may come from teaching and research institutions in France or abroad, or from public or private research centers.
L'archive ouverte pluridisciplinaire HAL, est destinée au dépôt et à la diffusion de documents scientifiques de niveau recherche, publiés ou non, émanant des établissements d'enseignement et de recherche français ou étrangers, des laboratoires publics ou privés. 


\title{
Mannose-targeted Mesoporous Silica Nanoparticles for Photodynamic Therapy.
}

\author{
David Brevet ${ }^{1 \S}$, Magali Gary-Bobo ${ }^{2 \S}$, Laurence Raehm ${ }^{1}$, Sébastien Richeter ${ }^{1}$, Ouahiba Hocine ${ }^{1}$, \\ Kassem Amro', Bernard Loock ${ }^{3 a, b}$, Pierre Couleaud ${ }^{4}$, 'Céline Frochot ${ }^{4}$, Alain Morère ${ }^{5}$, Philippe \\ Maillard $^{3 a, b *}$, Marcel Garcia ${ }^{2 *}$, Jean-Olivier Durand ${ }^{1 *},$. \\ (1) Université Montpellier 2, Institut Charles Gerhardt Montpellier, CNRS, UMR 5253, CC1701 Place Eugène Bataillon 34095 \\ Montpellier Cedex 5 France (2) IRCM, Institut de Recherche en Cancérologie de Montpellier, Montpellier, F 34298 France; \\ INSERM, Unité 896, Montpellier, F 34298 France ; Université Montpellier1, Montpellier, F 34298 France; CRLC Val \\ d'Aurelle Paul Lamarque, Montpellier, F 34298 France. (3a) UMR 176 CNRS/Institut Curie, Institut Curie, Bât 110, \\ Université Paris-Sud, F-91405 Orsay, France. (3b) Institut Curie, Section de Recherches, Centre Universitaire, Université \\ Paris-Sud, F-91405 Orsay, France. (4) Département de Chimie Physique des Réactions, UMR 7630, CNRS-INPL, ENSIC, 1, \\ rue Grandville BP 20451, 54001 Nancy Cedex, France. (5) UMR 5247 CNRS- UM 1 et 2 - Institut des Biomolécules Max \\ Mousseron, Ecole Nationale Supérieure de Chimie de Montpellier, 8 rue de l'Ecole Normale, 34296 Montpellier, France. \\ ${ }^{\S}$ These authors contribute equally to this work.
}

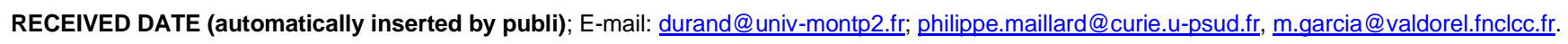

The design of functionalized mesoporous silica nanoparticles (MSN) has been challenging over the last few years. Due to their interesting properties (tunable size, high specific surface area, and narrow size pores distribution) major developments in the field of biology have been recently described and reviewed ${ }^{1-4}$. In the course of our program dealing with one and two-photon lightactivated $\mathrm{MSN}^{5,6}$, we were interested in photodynamic therapy (PDT) ${ }^{7}$ which is unprecedented with MSN. Several examples of silica-based nanoparticles for one ${ }^{8-13}$ and two-photon ${ }^{14}$ PDT applications have been described but the porosity of the silica was not controlled and the photosensitizer (PS) was physically entrapped inside the silica network which could lead to a premature release of the PS from the carrier, and thus to a reduced efficiency of treatment and to side effects. Covalent coupling of the PS inside the nanoparticles is expected to overcome this drawback. Only three recent examples involving the covalent attachment ${ }^{15-17}$ of the PS through trialkoxysilane groups to the silica matrix have been reported. Nevertheless none of these nanoparticles were functionalized by a biomolecule able to target cancer cells. As specific bioreceptors are overexpressed at the surface of cancer cells in many tumors ${ }^{18}$, functionalizing the nanoparticles in order to target these receptors would enhance the uptake of the nanoparticles by these cells. To date, only one example of silica-based nanoparticles functionalized with a monoclonal antibody in order to target breast cancer cells for PDT applications was described and the PS (merocyanine) was physically entrapped into the silica matrix ${ }^{19}$. Therefore, we present here the synthesis of novel MSN combining covalent anchoring of the photosensitizer to the mesoporous silica matrix and targeting of cancer cells with mannose attached on the surface of MSN. We show that those functionalized MSN were efficiently endocytosed through mannose receptors. PDT treatment ensured an efficient destruction of the cancer cells.

Scheme 1: Synthesis of NP1 : 1) $\mathrm{O}=\mathrm{C}=\mathrm{N}\left(\mathrm{CH}_{2}\right)_{3} \mathrm{Si}(\mathrm{OEt})_{3}$, EtOH. 2) $\left.\mathrm{Si}(\mathrm{OEt})_{4}, \mathrm{NaOH}, \mathrm{CTAB}, \mathrm{H}_{2} \mathrm{O} .3\right) \mathrm{HCl}, \mathrm{EtOH}$
In order to prepare the MSN, the key point was the use of a water-soluble photosensitizer. The anionic porphyrin 1 was prepared according to literature procedures ${ }^{20}$. The trialkoxysilane function was then introduced by using isocyanatopropyltriethoxysilane. The NP1 MSN synthesis was performed $^{5}$ with a proportion of $5 \mathrm{mg}(5.44 \mu \mathrm{mol})$ of PS 1 for $3.25 \mathrm{~g} \quad(15.7 \mathrm{mmol})$ of $\mathrm{Si}(\mathrm{OEt})_{4}$. The surfactant (cetyltrimethylammonium bromide $\mathrm{CTAB}$ ) was eliminated by treatment with $\mathrm{HCl}$ in $\mathrm{EtOH}$ at $60^{\circ} \mathrm{C}$. UV-visible spectra allowed the determination of the loading of the PS inside the nanoparticles which was found to be $3.5 \mu$ moles per gram of NP1. Transmission Electron Microscopy (TEM) showed monodispersed nanoparticles with a diameter of $100 \mathrm{~nm}$ for NP1. Dynamic light scattering (DLS) was in good agreement with TEM showing a hydrodynamic diameter of $150 \mathrm{~nm}$. $\mathrm{N}_{2}$ adsorption desorption confirmed the mesoporosity with a specific surface area of $860 \mathrm{~m}^{2} / \mathrm{g}$ and mesopores of $2.2 \mathrm{~nm}$ diameter. The nanoparticles were able to generate singlet oxygen as shown by ${ }^{1} \mathrm{O}_{2}$ phosphorescence measurements in EtOH. Rose Bengal was used as the standard reference. The quantum yield of ${ }^{1} \mathrm{O}_{2}$ production was calculated to be $57 \%$. The next step was the anchoring of the sugar moiety on the surface of the nanoparticles. Aminopropyltriethoxysilane (APTS) was first grafted on the surface of NP1 as described earlier ${ }^{6}$ to give NP2. Microanalysis and solid-state ${ }^{29} \mathrm{Si}$ DP MAS NMR showed a loading of about 1.5 mmol of amino groups per gram of NP2. The specific surface area dropped to $500 \mathrm{~m}^{2} / \mathrm{g}$ and the pore diameter diminished to $2.1 \mathrm{~nm}$, in agreement with a partial blocking of the pores by APTS treatment. DLS showed an increase of the hydrodynamic diameter to $170 \mathrm{~nm}$ which confirmed the grafting of APTS on the surface of NP2. Then diethyl squarate was used to link the supported amine groups with mannose. The ethyl squarate-functionalized mannose was synthesized ${ }^{21}$, and reacted with the amines on the surface of NP2. Titration ${ }^{22}$ of the supported carbohydrate by resorcinol in $\mathrm{H}_{2} \mathrm{SO}_{4}$ allowed determining a quantity of 0.180 mmoles of mannose per gram of $\mathbf{N P 3} .{ }^{13} \mathrm{C}$ CP MAS NMR confirmed the presence of the mannose moiety. 
In order to study the efficiency of these MSN for PDT, human breast cancer cells (MDA-MB-231) were incubated at different times with or without $20 \mu \mathrm{g} / \mathrm{ml}$ of MSN in the presence or absence of $10 \mathrm{mM}$ mannose and then submitted to monophotonic irradiation $\left(630-680 \mathrm{~nm} ; 6 \mathrm{~mW} / \mathrm{cm}^{2}\right)$ for $40 \mathrm{~min}$. A 3-(4,5-dimethylthiazol-2-yl)-2,5-diphenyltetrazolium bromide (MTT) $\operatorname{assay}^{15}$ was performed two days after irradiation, to establish the cytotoxicity of MSN.

First, as showed in Figure 1, the irradiation of cancer cells alone did not induce any toxicity. We then compared the cytotoxic efficiency of NP1 and NP3 on MDA-MB-231 cancer cells incubated for $24 \mathrm{~h}$ with MSN. NP1 incubated with cancer cells for $24 \mathrm{~h}$ and not submitted to irradiation, induced $7 \%$ cytotoxicity whereas their irradiation induced $45 \%$ cell death. In the same conditions, mannose-functionalized NP3 induced 19\% cell death without irradiation and $99 \%$ cell death when irradiated. The higher efficiency of mannose-functionalized MSN must be due to an active endocytosis via unidentified mannose receptors ${ }^{23}$.

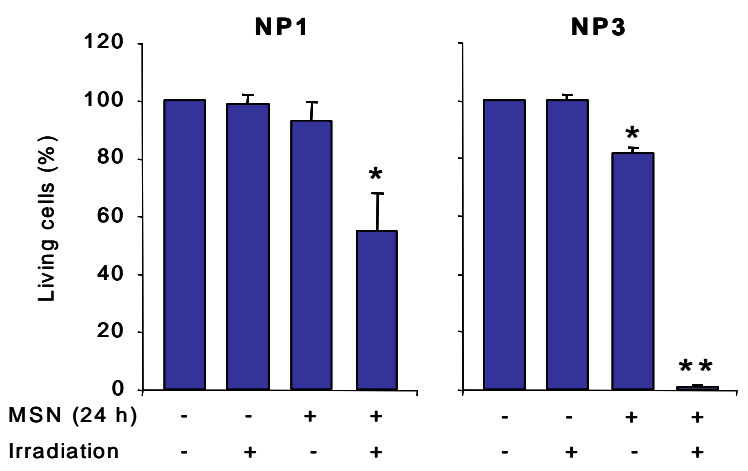

Figure 1 : PDT-induced cytotoxicities of NP1 and NP3.

Means \pm SD of 3 experiments. ${ }^{*} \mathrm{p}<0.05 ;{ }^{* *} \mathrm{p}<0.01$ Student's $t$ test.

To prove this, cancer cells were incubated for $1 \mathrm{~h}$ in a serum free medium with MSN, in presence or in absence of 10 $\mathrm{mM}$ mannose. Table 1 shows that cell irradiation without MSN pre-incubation did not induce any significant toxicity and neither did cell incubation with NP1 or NP3 without irradiation. By contrast, cell treatment with NP3 and submission to irradiation as already described, generated a significant cell death of $30 \%$. This effect was totally reversed (no significant cell death occurred) by incubating NP3 in the presence of mannose. This indicates that mannose acts as a competitor of NP3. Therefore, mannose receptors are involved in the active endocytosis of NP3, which thus have a higher therapeutic efficiency than NP1.

\begin{tabular}{|c|c|c|c|c|c|c|c|}
\hline$M S N(1 \mathrm{~h})$ & - & NP3 & NP3 & NP3 & NP3 & NP1 & NP1 \\
\hline Mannose & - & + & - & - & + & - & - \\
\hline Irradiation & - & - & - & + & + & - & + \\
\hline $\begin{array}{l}\% \text { cell } \\
\text { viability }\end{array}$ & 100 & $\begin{array}{l}99 \\
\pm 1\end{array}$ & $\begin{array}{l}101 \\
\pm 2\end{array}$ & $\begin{array}{l}70 \text { * } \\
\pm 6\end{array}$ & $\begin{array}{l}97 \\
\pm 5\end{array}$ & $\begin{array}{l}99 \\
\pm 2\end{array}$ & $\begin{array}{l}98 \\
\pm 2\end{array}$ \\
\hline
\end{tabular}

Table 1 : MSN cytotoxicity mediated through mannose receptors. Means \pm SD of 3 experiments. * $\mathrm{p}<0.05$ Student's $t$ test.

In conclusion, a new class of MSN was elaborated by covalent incorporation of a water-soluble PS and by covering the external surface with mannose residues. We have proved that these MSN presented a much higher in vitro photoefficiency in MDA-MB-231 cancer cells through mannose-dependent endocytosis than non functionalized nanoparticles. Studies are in progress to adapt these nanotools to in vivo PDT applications.
Acknowledgments: Financial support by ANR PNANO. 07-102 is gratefully acknowledged. We thank Dr Corine Gérardin for DLS Measurements.

\section{Notes and references :}

PM and CF are members of GDR 3049 "Medicaments Photoactivables-Photochimiothérapie (PHOTOMED)".

(1) Slowing, I. I.; Vivero-Escoto, J. L.; Wu, C.-W.; Lin, V. S. Y. Adv. Drug. Deliv. Rev. 2008, 60, 1278-1288.

(2) Trewyn, B. G.; Giri, S.; Slowing, I. I.; Lin, V. S. Y. Chem. Com. 2007, 3236-3245.

(3) Slowing, I. I.; Trewyn, B. G.; Giri, S.; Lin, V. S. Y. Adv. Func. Mater. 2007, 17, 1225-1236.

(4) Johansson, E.; Choi, E.; Angelos, S.; Liong, M.; Zink, J. I. J. Sol-Gel Sci. Technol. 2008, 46, 313-322.

(5) Lebret, V.; Raehm, L.; Durand, J. O.; Smaihi, M.; Gerardin, C.; Nerambourg, N.; Werts, M. H. V.; Blanchard-Desce, M. Chem. Mater. 2008, 20, 2174-2183.

(6) Lebret, V.; Raehm, L.; Durand, J. O.; Smaihi, M.; Werts, M. H. V.; Blanchard-Desce, M.; Methy-Gonnod, D.; Dubernet, C. J. Sol-Gel Sci. Technol. 2008, 48, 32-39.

(7) Bechet, D.; Couleaud, P.; Frochot, C.; Viriot, M.-L.; Guillemin, F.; Barberi-Heyob, M. Trends in Biotechnology, In Press.

(8) Liu, F.; Zhou, X.; Chen, Z.; Huang, P.; Wang, X.; Zhou, Y. Mater. Lett. 2008, 62, 2844-2847.

(9) Tada, D. B.; Vono, L. L. R.; Duarte, E. L.; Itri, R.; Kiyohara, P. K.; Baptista, M. S.; Rossi, L. M. Langmuir 2007, 23, 8194-8199.

(10) Tang, W.; Xu, H.; Kopelman, R.; Philbert, M. A. Photochem. Photobiol. 2005, 81, 242-249.

(11) Yan, F.; Kopelman, R. Photochem. Photobiol. 2003, 78, 587-591.

(12) Zhou, J.; Zhou, L.; Dong, C.; Feng, Y.; Wei, S.; Shen, J.; Wang, X. Mater. Lett. 2008, 62, 2910-2913.

(13) Roy, I.; Ohulchanskyy, T. Y.; Pudavar, H. E.; Bergey, E. J.; Oseroff, A. R.; Morgan, J.; Dougherty, T. J.; Prasad, P. N. J. Am. Chem. Soc. 2003, 125, 7860-7865.

(14) Kim, S.; Ohulchanskyy, T. Y.; Pudavar, H. E.; Pandey, R. K.; Prasad, P. N. J. Am. Chem. Soc. 2007, 129, 26692675.

(15) Ohulchanskyy, T. Y.; Roy, I.; Goswami, L. N.; Chen, Y.; Bergey, E. J.; Pandey, R. K.; Oseroff, A. R.; Prasad, P. N. Nano Lett. 2007, 7, 2835-2842.

(16) Lai, C.-W.; Wang, Y.-H.; Lai, C.-H.; Yang, M.-J.; Chen, C.-Y.; Chou, P.-T.; Chan, C.-S.; Chi, Y.; Chen, Y.-C.; Hsiao, J.-K. Small 2008, 4, 218-224.

(17) Rossi, L. M.; Silva, P. R.; Vono, L. L. R.; Fernandes, A. U.; Tada, D. B.; Baptista, M. S. Langmuir 2008, 24, 12534-12538.

(18) Low, P. S.; Henne, W. A.; Doorneweerd, D. D. Acc. Chem. Res. 2008, 41, 120-129.

(19) Zhang, P.; Steelant, W.; Kumar, M.; Scholfield, M. J. Am. Chem. Soc. 2007, 129, 4526-4527.

(20) Chen, Y.; Parr, T.; Holmes, A. E.; Nakanishi, K. Bioconjug. Chem. 2008, 19, 5-9.

(21) Sperling, O.; Fuchs, A.; Lindhorst, T. K. Org. Biomol. Chem. 2006, 4, 3913-3922.

(22) Park, I. Y.; Kim, I. Y.; Yoo, M. K.; Choi, Y. J.; Cho, M.H.; Cho, C. S. Int. J. Pharma. 2008, 359, 280-287.

(23) East, L.; Isacke, C. M. Biochem. Biophys. Acta 2002, 1572, 364-386. 


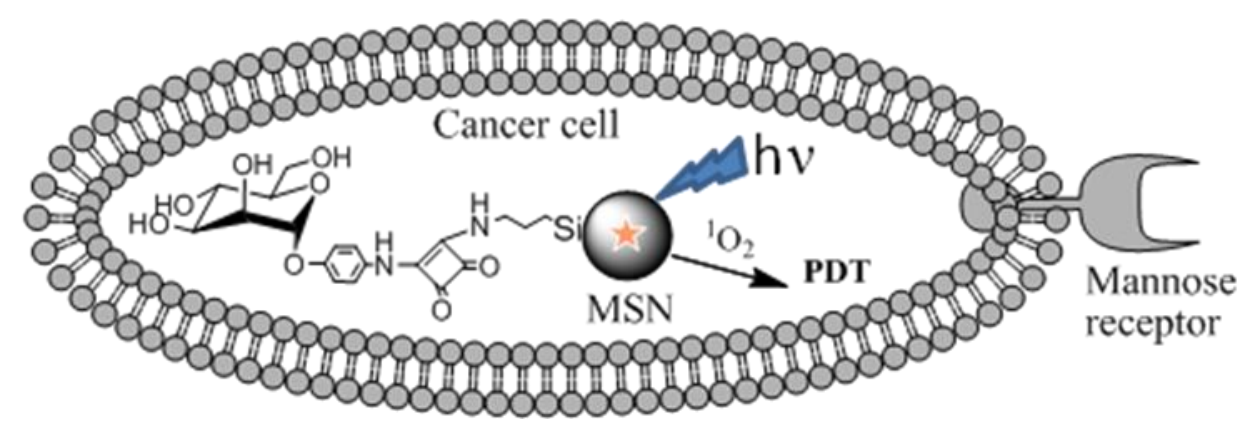

An efficient method for the synthesis of mesoporous silica nanoparticles with a covalent attachment of a photosensitizer inside the silica matrix for PDT applications is described. The surface of the nanoparticle was functionalized with mannose and the mannose-derivatized particles were much more efficient than non functionalized ones for the treatment of cancer cells. 